\title{
Fiskekonsum og kreftrisiko blant norske kvinner - The Norwegian Women and Cancer Study (NOWAC)
}

\author{
Anette Hjartåker ${ }^{1,2}$, Dagrun Engeset ${ }^{1}$, Magritt Brustad ${ }^{1}$ og Eiliv Lund ${ }^{1}$ \\ ${ }^{l}$ Institutt for samfunnsmedisin, Universitetet $i$ Tromsø \\ ${ }^{2}$ Seksjon for medisinsk statistikk, Universitetet $i$ Oslo
}

Korrespondanse: Anette Hjartåker, IMBA, Seksjon for medisinsk statistikk, postboks 1122 Blindern, 0317 Oslo

Telefon: 22851047 Telefax: 22851313 e-post: anette.hjartaker@basalmed.uio.no

\begin{abstract}
SAMMENDRAG
Ved Institutt for samfunnsmedisin, Universitetet i Tromsø, er det over mange år bygget opp en landsdekkende prospektiv undersøkelse kalt 'Kvinner, livsstil og helse'/'Kvinner og kreft'. Studien er primært designet for å undersøke risikofaktorer for kreft, og i særdeleshet brystkreft. Siden 1991 har drøyt 100000 tilfeldig utvalgte kvinner, født 1927-1965, blitt inkludert i studien. Svarprosenten er omlag 60. Deltakerne har fylt ut et spørreskjema med noe varierende innhold, men med en del felles kjernespørsmål. Detaljgraden når det gjelder kostholdsinformasjon varierer. Av de vel 100000 kvinnene som deltar har omlag halvparten fylt ut et oppfølgingsskjema. Vi er særlig interessert i å studere en eventuell effekt av et høyt fiskekonsum på kreftrisiko. Spørsmålene om konsum av fisk og fiskeprodukter er validert mot fettsyresammensetningen i serum fosfolipider. Studien inngår i multi-senter prosjektet EPIC - the European Prospective Investigation into Cancer and Nutrition. For å kunne sammenlikne kostdata fra de ti deltakerlandene er det utarbeidet en intern kalibreringsmetode basert på et strengt standardisert dataprogram for 24-timers kostholdsintervju. I Norge vil det bli gjennomført omlag 1800 kostholdsintervju over telefon.
\end{abstract}

Hjartåker A, Engeset D, Brustad M, Lund E. Fish consumption and cancer risk among Norwegian women - The Norwegian Women and Cancer Study (NOWAC). Nor J Epidemiol 2000; 10 (1): 63-70.

\section{ENGLISH SUMMARY}

The Norwegian Women and Cancer study, NOWAC (in Norwegian: 'Kvinner, livsstil og helse'/'Kvinner og kreft') is a large population-based cohort study primarily designed to examine factors related to cancer, other illnesses, and mortality in a prospective manner. In particular, it is designed for investigation of breast cancer. Since the establishment in 1991, more than 100000 Norwegian women born 1927-1965 have been included in the cohort. The participants are randomly sampled, and the response rate is about $60 \%$. The participants have received a mailed letter of invitation requesting informed consent and a self-instructive questionnaire. After sufficient follow-up time, events will be identified by linkage to the Cancer Registry of Norway and to the registry of death certificates at Statistics Norway. Dietary data have been collected through a food frequency approach. Some 70000 women have given detailed information about their diet during the last year, whereas more scarce dietary data are collected from the rest of the participants. A large number of the women have reported their dietary intake twice. Along with information on "usual" diet, special attention is given to the consumption of marine foods. Based on earlier findings we want to examine a potential protective effect of fish consumption on breast cancer risk. The questions on marine food consumption have been validated against serum phospholipid fatty acid composition. In addition to the national analyses, NOWAC is part of the large multi-centre study EPIC - the European Prospective Investigation into Cancer and Nutrition. To calibrate dietary data across centres a computer based 24-h recall program is developed. A sub-sample of about 1800 of the NOWAC participants will be interviewed using this program. The interviews are performed by telephone. Building a biological bank is another important part of EPIC, and we are planning to collect blood samples via mail for a sub-sample of the Norwegian participants.

\section{BAKGRUNN}

Det har lenge vært store forventninger knyttet til muligheten av å forebygge kreft gjennom kostholdsendringer (1). Det er imidlertid stor uenighet angående dette. En ekspertgruppe nedsatt av Nordisk ministerråd fant at det var så stor usikkerhet knyttet til vurderingen av årsaksforholdene mellom kosthold og kreft at de ikke anga noe potensiale for forebygging, men etterlot en rekke spørsmålstegn (2). En av grunnene til det var 


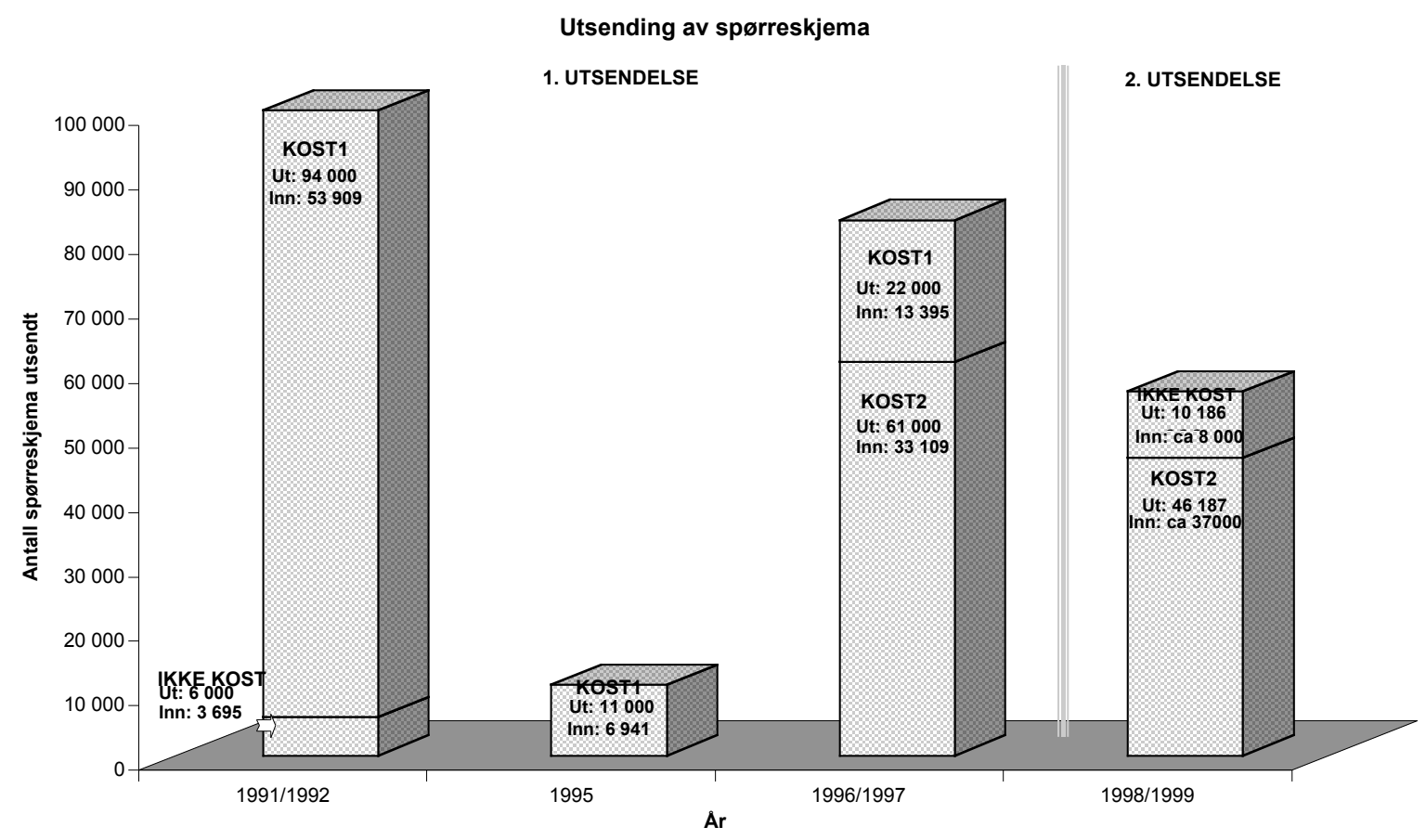

Figur 1. Oversikt over tidspunkt for utsendelse av spørreskjema med antall utsendte og innkomne skjema, samt type spørreskjema.

manglende informasjon om kostholdet i Norden, samt motstridende resultater fra epidemiologisk forskning.

Ved Institutt for samfunnsmedisin, Universitetet i Tromsø, er det over mange år bygget opp en landsdekkende prospektiv undersøkelse over risikofaktorer for kreft hos kvinner under betegnelsene 'Kvinner, livsstil og helse'/'Kvinner og kreft' (på engelsk 'the Norwegian Women and Cancer Study', NOWAC). Totalt 104108 kvinner i alderen 30-70 år har fylt ut et spørreskjema med noe varierende innhold, men med en del felles kjernespørsmål. En beskrivelse av variabler og svarprosenter er gitt tidligere $(3,4)$.

Første del av undersøkelsen ble gjennomført i årene 1991/92 da 100000 kvinner i alderen 34-49 år fikk tilsendt et spørreskjema om risikofaktorer for kreft. De fleste kvinnene fikk tilsendt et skjema som blant annet inneholdt et begrenset antall spørsmål om kostholdet, heretter omtalt som Kost1 (Figur 1 og Appendix 1). I alt 57604 kvinner returnerte et utfylt spørreskjema med samtykke til kobling mot Kreftregisteret og Dødsårsaksregisteret. Av disse hadde 53909 kvinner besvart spørsmål om kostholdet sitt. I 1995 ble ytterligere 11000 kvinner i alderen 30-44 år tilsendt et spørreskjema der det inngikk spørsmål om kostholdet tilsvarende Kost1. Knapt 7000 kvinner besvarte skjemaet.

Etter publisering av hypoteser om en mulig forebyggende effekt på brystkreft som følge av et høyt fiskekonsum $(5,6)$, ble det i årene 1996/97 gjennomført utprøving av skjemaer med varierende omfang der kostholdet, og særlig fiskekonsumet, fikk en framtredende plass. Skjema med en bred dekning av kost- holdet (kalt Kost2, Appendix 2) ble sendt til 61000 kvinner i alderen 40-70 år, mens 22000 kvinner i samme alder fikk spørreskjema med kostholdsspørsmål tilsvarende Kost1. I denne utsendingen besvarte 33109 kvinner Kost2 og 13395 kvinner Kost1 (Figur 1).

I 1998 fikk vi muligheten til å henvende oss med et nytt spørreskjema, dels på fire sider uten kostholdsspørsmål ( $\mathrm{n}=10$ 186) og dels på åtte sider med kostholdsspørsmål $(\mathrm{n}=46$ 187), til kvinnene som var med i første omgang i 1991/92 (1231 kvinner kunne ikke kontaktes på grunn av emigrasjon, død, m.m.). Vi fikk tilbake i alt ca. 8000 skjema uten kostholdsopplysninger og ca. 37000 skjema med kostholdsopplysninger. Kostholdsspørsmålene som ble besvart av de 33000 kvinnene som fikk forespørsel i 1996/97 og de 37000 som besvarte et spørreskjema for andre gang i 1998 er nesten identiske (Kost2). Det betyr at oppfølgingsstudien i tillegg til opplysinger om hormonbruk, røyking, fysisk aktivitet, alkohol, sosiale forhold, egen rapportert sykdom og helsetilstand, solvaner, fertilitet osv. også har detaljerte kostholdsopplysninger fra omlag 70000 kvinner.

I løpet av de årene vi har bygget opp kohortundersøkelsen har interessen for fiskekonsumets betydning for helse generelt, og kreft spesielt, økt internasjonalt. Vi har beholdt vårt naturlige fortrinn med en fiskespisende befolkning (7). Særlig når det gjelder inntaket av mager fisk som torsk og sei har Norge et høyt forbruk.

$\mathrm{Vi}$ vil i det følgende presentere spørreskjemaene som er brukt til å samle inn kostholdsdataene og en tilhørende validering til Kost2. Videre presenterer vi 
det internasjonale samarbeidet vi har med 'European Prospective Investigation into Cancer and Nutrition', EPIC.

\section{SPØRRESKJEMAENE}

Som nevnt inngår det flere skjemavarianter både i Kost1 og i Kost2. Den innbyrdes variasjonen for Kost1 og for Kost2 er imidlertid liten, og vi vil derfor omtale alle Kost1-skjemaene under ett og tilsvarende for Kost2.

Som vist i Appendix 1 inneholder Kost1 spørsmål om gjennomsnittlig bruk av 20 matvarer samt alkoholholdige drikker det siste året. Matvarene som inngår er ikke valgt ut med henblikk på spesielle næringsstoff eller matvaregrupper, men er snarere et utvalg av vanlig brukte næringsmidler i Norge. Data fra Kost1 egner seg først og fremst til frekvensanalyser av matvarer. Meningsfulle næringsberegninger vil være vanskelig.

Kost2 (Appendix 2) inneholder 75-85 frekvensspørsmål om matvarer som tradisjonelt blir brukt i Norge. Skjemaet er særlig designet med tanke på å estimere inntaket av fisk og fiskeprodukt, selv om det også er tenkt å skulle dekke det 'vanlige' kostholdet. Dataene kan brukes både på frekvens- og næringsstoffnivå. Til å næringsberegne kostinntaket er det laget et eget dataprogram i statistikkpakken SAS (8). Vekter og porsjonstørrelser i programmet er i hovedsak hentet fra 'Mål og vekt for matvarer' (9), mens næringsstoffverdier er hentet fra Matvaretabellen 1995 (10). Basert på disse beregningene har vi publisert kostholdsdata for knapt 10000 kvinner som inngår i studien (11). Kost2 er foreløpig validert som omtalt nedenfor.

For flere helseproblemer og sykdommer kan kosten i barneårene være av betydning (12). Både Kost1 og Kost2 inneholder derfor også noen frekvensspørsmål om kostholdet som barn.

\section{Validering av Kost2}

Før utsending av Kost2 ble det gjennomført en evaluering av spørsmålene om fisk og fiskeprodukt (13). A bruke biologiske variabler ved validering av spørreskjemaopplysinger er gunstig med tanke på å unngå korrelerte målefeil mellom metodene. Marine matvarer har en unik posisjon i det norske kostholdet når det gjelder å bidra til inntaket av omega-3 fettsyrer. Dette kan man dra nytte av i en evalueringssituasjon etter som inntaket av fettsyrer kan reflekteres i ulike biologiske variabler (14). Vi valgte å bruke fettsyresammensetningen i serum fosfolipider som biologisk markør. Fettsyresammensetningen i serum fosfolipider er antatt å være relativt stabil overfor korttidsendringer i kosten.

Valideringsstudien ble gjennomført i Trondheim høsten 1995 i forbindelse med 40-års undersøkelsen til Statens helseundersøkelser. Alle kvinner som møtte til 40-års undersøkelsen i perioden 13.-22. november ( $\mathrm{n}=$ 265) ble invitert til å delta i valideringsstudien, med unntak av ni kvinner som ikke hadde tilstrekkelige norsk-kunnskaper eller som ankom etter stengetid. De 256 mulige deltakerne fikk skriftlig og muntlig informasjon om valideringsstudien, og 242 personer $(94,5 \%)$ sa seg villige til å delta. Kvinnene ble bedt om å svare på et kostholdsskjema (som senere dannet grunnlaget for Kost2), og det ble tatt en $10 \mathrm{ml}$ blodprøve. Blodprøveanalysene ble foretatt ved Regionsykehuset i Trondheim ved hjelp av prosedyrer som er beskrevet tidligere (13). Seks kvinner fullførte ikke utfyllingen av spørreskjemaet, mens to kvinner ikke leverte blodprøve. Det endelige deltakerantallet i studien var derfor $234(91,4 \%)$.

Spørreskjemaet var bygd opp som et semikvantitativt matvarefrekvensskjema der konsumet av marine næringsmidler stod i fokus, men der en rekke andre næringsmidler også var inkludert. Det var i alt 22 spørsmål om fiskekonsum fordelt på følgende kategorier: skalldyr, fisk som pålegg, mager fisk, fet fisk, fiskemat og innmat fra fisk. For konsumet av mager og fet fisk ble det spurt om eventuelle årstidsvariasjoner i inntaket. Skjemaet inneholdt også flere spørsmål om bruk av tran i ulike årstider og av fiskeoljekapsler. Som for Kost2 (Appendix 2) var det hovedsakelig oppgitt seks-sju frekvensalternativer med tilhørende spørsmål om porsjonsstørrelse for hver matvare.

Skjemaet inkluderte også to enkle frekvensspørsmål om fisk som er brukt i Kost1. Dette ble gjort for å undersøke i hvilken grad resultatet fra disse samsvarte med resultatet fra de mer omfattende fiskespørsmålene som ble brukt i Kost2.

Resultatene viste at inntaket av fisk og fiskeprodukter kunne gjenspeiles i omega-3 fettsyresammensetningen i serum fosfolipidene. Graden av assosiasjon syntes å være relatert til omega-3 fettsyreinnholdet $i$ fisken som ble konsumert. Konsumet av mager fisk og av fiskemat (vanligvis basert på magre fiskeslag) var knapt relatert til omega-3 fettsyresammensetningen i serum fosfolipidene, mens konsumet av fet fisk og særlig tran, viste en signifikant positiv assosiasjon. Assosiasjonene ble moderat forsterket når opplysninger om porsjonsstørrelse ble benyttet i tillegg til frekvensinformasjonen. En betydelig sterkere assosiasjon oppnådde man først ved beregning av omega-3 fettsyreinntaket. Spearmans korrelasjonskoeffisient mellom inntak av eicosapentaensyre (EPA, 20:5n-3) og serum fosfolipid EPA var 0,58, og korrelasjonskoeffisienten mellom inntak av docosahexaensyre (DHA, 22:6n-3) og serum fosfolipid DHA var 0,53 (13).

De to enkle frekvensspørsmålene som ble brukt i Kost1 gav omlag samme gjennomsnittlige inntak av fisk som de nye, mer omfattende spørsmålene i Kost2. Det var imidlertid ingen signifikant assosiasjon mellom inntaket av fisk og fettsyresammensetningen i serum fosfolipider når man benyttet de enkle spørsmålene (13). Dette er verdt å merke seg etter som mange spørreskjema kun inneholder få spørsmål om konsum av fisk og fiskeprodukt. Selv om summasjonsspørsmål kan gi brukbare gjennomsnittstall, er ikke validiteten nødvendigvis god nok. 


\section{OPPFØLGING}

Studien er godkjent av Etisk komité for Nord-Norge (REC V) og Datatilsynet har gitt tillatelse til oppbevaring av persondata og kobling mot Kreftregisteret og Dødsårsaksregisteret. Alle spørreskjema som returneres til Institutt for Samfunnsmedisin er kun påført et løpenummer som identifikasjon. Ved koblinger mot registrene vil identifisering av løpenumrene først skje i Statistisk Sentralbyrå.

De første oppfølgingsanalyser er beregnet å starte etter omlag fem år. Dette bygger på en beregning av statistisk styrke der en ønsker å finne en redusert risiko på $25 \%(\mathrm{RR}=0,75)$ for brystkreft gitt en kostholdsfaktor (mager fisk) der $30 \%$ er høyt eksponert $(\square=$ 0,05 , power $=0,80$ ).

\section{EPIC-STUDIEN}

I tillegg til det nasjonale arbeidet i 'Kvinner og kreft' inngår prosjektet i EPIC-samarbeidet. EPIC-studien (15) er en multisenter prospektiv kohortstudie som omfatter ti europeiske land (Spania, Italia, Frankrike, Hellas, Tyskland, Nederland, Storbritannia, Sverige, Danmark og Norge). Hovedsenteret ligger hos 'The International Agency for Research on Cancer' (IARC, WHO), i Lyon, Frankrike. 'Kvinner og kreft'-undersøkelsen ble en del av EPIC i 1998. EPIC-studien kombinerer epidemiologiske- og laboratoriemetoder for å undersøke sammenhengen mellom ernæring og kreft. Hvert deltakerland har estimert det vanlig kostholdet på individnivå ved hjelp av ulike kostholdsmetoder (f.eks. spørreskjema, registrering). For å kunne sammenlikne data som er samlet inn i ulike land og med ulikt studiedesign, er det utarbeidet en intern kalibreringsmetode basert på et standardisert dataprogram for 24-timers kostholdsintervju, kalt EPICsoft (16). Subpopulasjoner på mellom 1200 og $5000 \mathrm{av}$ den totale kohorten i hvert land har blitt tilfeldig valgt ut for å delta i et 24-timers kostholdsintervju (16).

\section{4-timers intervju og oppbyggingen av EPIC-soft}

Ved 24-timers kostholdsintervju blir informanten bedt om å rapportere alt som er drukket og spist de siste 24 timene eller den foregående dagen. Metoden gir data for gjennomsnittlig kostinntak på gruppenivå (17).

EPIC-soft er standardisert; det vil si at oppbyggingen av programmet er lik i alle land. Hvert land har likevel sin landsspesifikke versjon der matvarer og matretter fra de ulike landene er lagt inn. "Ryggsøylen" i programmet er en matvareliste. I den norske versjonen av programmet ligger det omlag 1700 matvarer i listen. Matvarelisten deles inn i 17 hovedgrupper med ulikt antall undergrupper. Med basis i denne listen er det laget flere ulike filer som beskriver matvarene ytterligere, noe som gjør at matvarelisten indirekte blir utvidet. Under intervjuingen må man blant annet velge 'fasetter' som fysisk form (f.eks. hel eller moset), tillagingsmetode (kokt, stekt, bakt osv.), oppbevaringsmetode, hermetiseringsmedium og smakstilsetning for matvaren. Det finnest i alt 16 ulike fasetter med et ulikt antall tilhørende beskrivende karakteristika. Ikke alle fasettene er tilgjengelige eller aktuelle for alle matvarene.

Det ligger også flere "skjulte" omregningsfiler i programmet. Ved å velge ulike fasetter eller kvantifiseringsmetoder vil programmet automatisk gjøre en omregning ut fra de koeffisientene som er lagt inn i disse filene. Et eksempel på dette kan være fiskefilet panert i mel og stekt i fett. Programmet vil ut fra disse opplysningene oppgi hvor stor mengde fett intervjuobjektet har fått i seg via fisken basert på omregningsfaktoren for denne bearbeidingsmetoden.

Mengden mat/drikke som er konsumert kan kvantifiseres på flere ulike måter. Hver enkelt matvare har en eller flere forhåndsvalgte kvantifiseringsmetoder som husholdningsmål, gram eller volum, ulike standardenheter (f.eks. liten, medium eller stor), eller bilde. Bildene som blir brukt viser ulike porsjonsstørrelser av forskjellige matvarer eller matretter. EPIC-senteret har laget en billedserie med i alt 140 matvarer/matretter. Hver av seriene består av fire til seks bilder. Av disse har vi i Norge valgt ut en serie med 46 matvarer/-retter bestående av tre til seks bilder. Disse er videre forminsket noe og satt inn i en brosjyre sammen med ulike skisser av brødskiver i naturlige størrelser og bilder av kopper og glass.

\section{4-timers intervju i Norge}

Målet er å intervjue 1800 norske kvinner fra 'Kvinner, livsstil og helse'/'Kvinner og kreft' kohorten. Kvinnene som deltar i 24-timers intervju er tilfeldig valgt ut og er i aldersgruppen 42-56 år. Alle deltakerne får tilsendt et invitasjonsbrev med svarslipp samt billedbrosjyren før intervjuet. På svarslippen kan de krysse av om de ønsker å delta eller ikke, og for hvilket tidspunkt som passer best. Alternativene er hverdag og helg, og dagtid (kl. 9-15), ettermiddag (kl. 17-19), kveld (kl. 19-21). Invitasjonen til å bli med i intervjuundersøkelsen går ut i puljer på 500. To uker etter at invitasjonsbrevet er sendt, får alle tilsendt et kombinert påminnings- og takkekort. Statistisk sentralbyrå er ansvarlig for utsendelsene og for utvelgelse av deltakerne. Intervjuingen startet i mai 1999 og vil pågå fram til og med april 2000. Intervjuene blir fordelt på alle dager i uken og går over ett år for å dekke årstidsvariasjoner i kostholdet. Så langt i undersøkelsen har i overkant av $50 \%$ av de spurte sagt seg villig til å delta i kostholdsintervjuet. Et intervju tar vanligvis omlag 30 minutter.

I motsetning til Norge har de andre EPIC-landene ikke landsdekkende kohorter, men har utvalg fra bestemte områder og byer. Det har dermed vært mulig å gjennomføre intervjuer med personlig frammøte. Grunnet store geografiske avstander og en begrensende tidsfaktor, ville intervju med personlig frammøte bli 
svært kostbart å utføre i Norge. Av praktiske årsaker valgte vi derfor å utføre intervjuene pr. telefon. For å validere telefonintervjuene vil det bli foretatt $\mathrm{i}$ overkant av 100 intervju med personlig frammøte i Tromsø. Disse vil bli sammenlignet med et tilsvarende antall telefonintervjuer av kvinner i Tromsø. En slik validering er viktig når de norske resultatene skal sammenlignes med resultatene fra de andre EPIClandene.

Intervjuene blir i hovedsak utført av personer med ernæringsfaglig bakgrunn. Intervjuene vil bli sendt til EPIC-senteret i Lyon for videre databearbeiding og analyse. Første trinn i analyseringen vil foregå på matvarenivå. Neste trinn vil foregå på næringsstoffnivå. Innen de enkelte land kan nasjonale matvaretabeller benyttes, men for sammenligning av inntak av næringsstoffer mellom landene må det utarbeides en standardisert matvaretabell (18). EPIC-senteret jobber i dag med å utarbeide en slik tabell, i samarbeid med de ti deltakerlandene.

I tillegg til kostholdsopplysningene fra spørreskjemaer og fra 24-timers intervju samles det inn biologisk materiale i forbindelse med EPIC-studien. I Norge planlegger vi innsamling av blod pr. post. Et pilotforsøk med innsamling av blodprøver fra kvinner i Tromsø er i gang. Fram til juni 2000 vil omlag 100 kvinner som møter til personlig kostintervju også bli bedt om å ta en blodprøve.

\section{AVSLUtning}

'Kvinner, livsstil og helse'/'Kvinner og kreft' er den største ernæringsepidemiologiske undersøkelsen knyttet til kreft som er blitt gjennomført i Norge. Selv om hovedformålet er å undersøke eventuelle samband mellom fiskekonsum og kreftrisiko, gir undersøkelsen også gode muligheter til å belyse andre problemstillinger knyttet til kosthold og helse. I årene framover vil vi kunne koble kostholdsopplysninger mot en rekke krefttyper og dødsårsaker. Tilknytningen til EPICstudien gir gode muligheter til et verdifullt internasjonalt samarbeide. Den planlagte innsamlingen av blodprøver vil forsterke kohortens potensiale ytterligere.

\section{REFERANSER}

1. Food, nutrition and the prevention of cancer: a global perspective. American Institute of Cancer Research, Washington, 1997.

2. Nordisk ministerråd. Årsager til kreft i Norden og muligheder for forebyggelse. NORD 1997; 20.

3. Lund E, Kumle M, Sandaune A-G. Flyttemønsterets betydning for selvvurdert helse blant norske kvinner i alderen 34-69 år. Tidsskr Nor Lageforen 1998; 118: 3752-3755.

4. Lund E, Gram IT. Response rate according to title and length of questionnaire. Scand J Soc Med 1998; 26: 154-160.

5. Lund E, Bønaa K. Reduced breast cancer mortality among fishermen's wives in Norway. Cancer Causes Control 1993; 4: 283-287.

6. Lund E (editorial). The research tide ebbs for the dietary fat hypothesis in breast cancer. Epidemiology 1994; 5: 549-556.

7. Statens råd for ernæring og fysisk aktivitet. Utvikling i norsk kosthold. Rapport nr. 1, 1999.

8. SAS Institute Inc., Version 6, Cary, NC 27513, 1995.

9. Landsforeningen for kosthold og helse. Mål og vekt for matvarer. Otta: Engers boktrykkeri, 1989.

10. Statens ernæringsråd og Statens næringsmiddeltilsyn. Den store matvaretabellen 1995. Oslo: Universitetsforlaget, 1995.

11. Hjartåker A, Lund E. Relationship between dietary habits, age, lifestyle, and socio-economic status among adult Norwegian women. The Norwegian Women and Cancer Study. Eur J Clin Nutr 1998; 52: 565-572.

12. Kemm JR. Eating patterns in childhood and adult heath. Nutr Health 1987; 4: 205-215.

13. Hjartåker A, Lund E, Bjerve KS. Serum phospholipid fatty acid composition and habitual intake of marine foods registered by a semi-quantitative food frequency questionnaire. Eur J Clin Nutr 1997; 51: 736-742.

14. Riboli E, Rönnholm H, Saracci R. Biological markers of diet. Cancer Surv 1987; 6: 685-718.

15. Riboli E. Nutrition and cancer: Background and rationale of the European Prospective Investigation into Cancer and Nutrtion (EPIC). Ann Oncol 1992; 3: 783-791.

16. Slimani N, Deharveng G, Charrondière RU, Van Kappel AL, Ocké MC, Welch A, et al. Structure of the standardized computerized 24-h diet recall interview used as reference method in the 22 centers participating in the EPIC project. Comp Met Prog Biomed 1999; 58: 251-266.

17. Cameron ME, Van Staveren WA. Manual on methodology for food consumption studies. Oxford University Press, 1988 .

18. Deharveng G, Charrondière RU, Slimani N, Southgate DAT, Riboli E. Comparison of nutrients in the food composition tables available in the nine European countries participating in EPIC. Eur J Clin Nutr 1999; 53: $60-79$. 
Appendix 1. KOST1.

\section{Kosthold}

For hver matsort nedenfor ber vi deg krysse av i den ruten som passer hvor ofte du i gjennomsnitt i lepet av siste år har spist slik mat.

$\begin{array}{rrrrrrrrr}6-10 & 4-5 & 2-3 & 1 & 5-6 & 2-4 & 1 & 1-3 & \text { Nesten } \\ \text { pr } & \text { pr } & \text { pr } & \text { pr } & \text { pr } & \text { pr } & \text { pr } & \text { pr } & \text { aldri }\end{array}$ dag dag dag dag uke uke uke măned

Helmelk (glass) Skummet melk (glass)

Lettmelk (glass)

Kokekaffe (kopper)

Traktekaffe (kopper)

Pulverkaffe (kopper)

Grov brød (skiver)

Fint bred (skiver)

Ost (skiver)

Poteter

Epleripærer

Appelsiner 0.l.

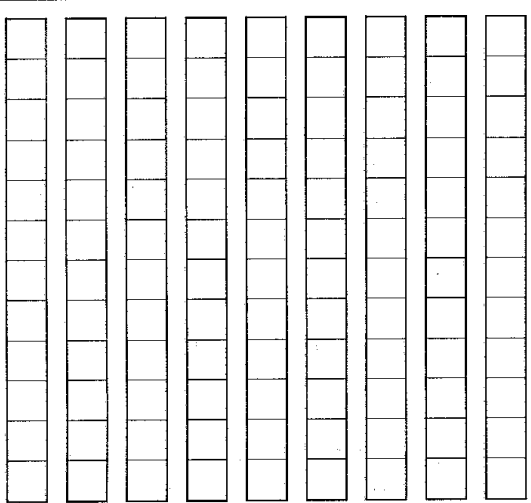

\begin{tabular}{|c|c|c|c|c|c|c|c|c|}
\hline Middag & $\begin{array}{r}6-7 \\
\mathrm{pr} \\
\text { uke }\end{array}$ & $\begin{array}{r}4.5 \\
\text { pr } \\
\text { uke }\end{array}$ & $\begin{array}{r}3 \\
\text { pr } \\
\text { uke }\end{array}$ & $\begin{array}{r}2 \\
\text { pr } \\
\text { uke }\end{array}$ & $\begin{array}{r}1 \\
\text { pr } \\
\text { uke }\end{array}$ & $\begin{array}{r}2-3 \\
\mathrm{pr} \\
\text { måned }\end{array}$ & $\begin{array}{r}1 \\
\text { pr } \\
\text { mảned }\end{array}$ & $\begin{array}{l}\text { Nesten } \\
\text { aldri }\end{array}$ \\
\hline
\end{tabular}

\section{Rent kjøtt}

Oppmalt kjøtt

Fet fisk (makrell,laks o.l)

Mager fisk (torsk ol.)

Ris, spaghetti

Gulerotter

Kål

Kålrot

Salat

Broccoli/Blomkåal

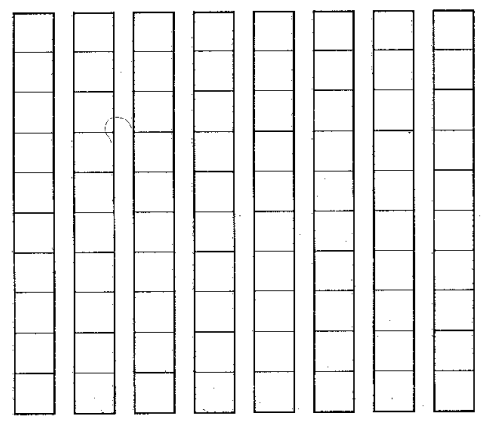

Hva slags fett blir vanligvis brukt i din husholdning?

På Til

brød matlaging

Smør eller hard margarin .........

Myk (soft) margarin eller olje .......

Smør/margarin blanding

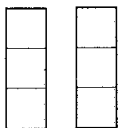

Hvor mye melk drakk du som barn hver dag?

$\square$ drakk ikke melk $\square$ 1-3 glass $\square$ 4-6 glass $\square$ 7 glass eller mer

Hvor ofte spiste du grønnsaker til middag som barn?

$\square$ aldri $\square$ 1 gang i uken eller mer sjelden

2-3 ganger i uken $\square 4$ eller flere ganger

\section{Alkohol}

Er du total avholdskvinne?

$\mathrm{Ja} \quad \mathrm{Nei}$

Hvis Nei, hvor ofte og hvor mye drakk du i gjennomsnitt siste året?

$$
\begin{aligned}
& \text { 6-10 4-5 2-3 } \quad \begin{array}{llllll}
5-6 & 2-4 & 1 & 1-3 & \text { Nester }
\end{array} \\
& \text { pr pr pr pr pr pr pr pr aldr } \\
& \text { dag dag dag dag uke uke uke måned }
\end{aligned}
$$

$\emptyset \mathrm{(1/2} \mathrm{liter)}$

Vin (glass)

Brennevin(drinker)

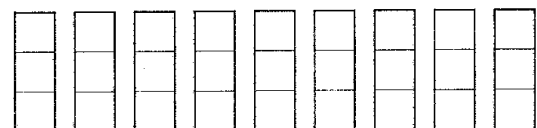


Appendix 2. KOST2.

\section{Kosthold}

Vi er interessert i å få kjennskap til hvordan kostholdet ditt er vanligvis. Kryss av for hvert spørsmål om hvor ofte du i gjennomsnitt siste året har brukt den aktuelle matvaren, og hvor mye du pleier å spise/drikke hver gang.

Hvor mange glass melk drikker du vanligvis av hver type? (Sett ett kryss pr. linje)

aldri/ $1-4 \mathrm{pr} .5-6$ pr. 1 pr.
sjelden uke uke dag dag dag

Helmelk (søt, sur)

Lettmelk (søt, sur)

Skummet (søt, sur)

Hvor mange kopper kaffe drikker du vanligvis av hver sort? (Sett ett kryss for hver linje)

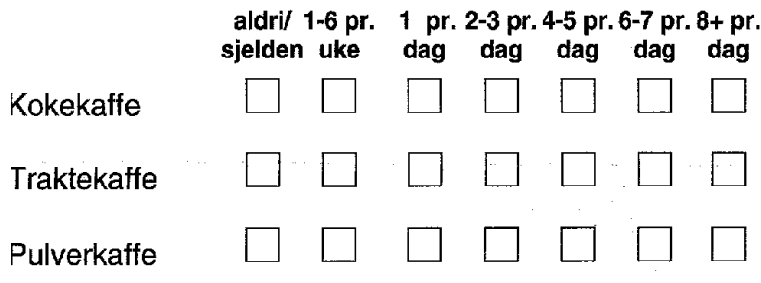

Hvor mange glass juice, saft og brus drikker du vanligvis? (Sett ett kryss for hver linje)

$$
\text { aldri/ 1-3 pr. 4-6 pr. } 1 \text { pr. 2-3 pr. } 4+\text { pr. }
$$$$
\text { sjelden uke uke dag dag dag }
$$

Appelsinjuice

Saft/brus med sukker

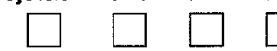

Saft/brus sukkerfri

Hvor ofte spiser du yoghurt ( 1 beger)? (Sett ett kryss)

$\square$ aldri/sjelden $\square$ 1 pr. uke $\square$ 2-3 pr. uke $\square$ 4+ pr. ukc

Hvor ofte har du i gjennomsnitt siste året spist kornblanding, havregryn eller müsli? (Sett ett kryss)

$\square$ aldri/nesten aldri $\square_{1-3 \text { pr. uke }} \square_{\text {4-6 pr. uke }} \square_{1 \text { pr. dag }}$

Hvor mange skiver brød/rundstykker og knekkebrod/skonrokker spiser du vanligvis? (1/2 rundstykke $=1$ bredskive) (Sett ett kryss for hver linje)

\begin{tabular}{|c|c|c|c|c|c|c|}
\hline & $\begin{array}{c}\text { aldrit } \\
\text { sjelden }\end{array}$ & $\begin{array}{l}14 \mathrm{pr} \text {. } \\
\text { uke }\end{array}$ & $\begin{array}{l}5.7 \mathrm{pr} \\
\text { uke }\end{array}$ & $\begin{array}{l}2-3 \text { pr } \\
\text { dag }\end{array}$ & $\begin{array}{r}4.5 \mathrm{pr} \\
\mathrm{dag}\end{array}$ & $\begin{array}{r}6+\mathrm{pr} \\
\mathrm{dag}\end{array}$ \\
\hline \multicolumn{7}{|l|}{ Grovt brod } \\
\hline Fint brod & & & & & & \\
\hline Knekkebrad ol & & & & & & \\
\hline
\end{tabular}

Nedentor er det spørsmal om bruk av ulike paleggstyper. Vi spør om hvor mange brødskiver med det aktuelle pâlegget du pleier á spise. Dersom du også bruker matvarene $i$ andre sammenhenger enn til brød (f. eks. til vafler, frokostblandinger, grøt), ber vi om at du tar med dette når du besvarer spørsmålene.

På hvor mange brødskiver bruker du? (Sett ett kryss pr. linje)

\begin{tabular}{|c|c|c|c|c|c|c|}
\hline SY) & opr. & Hore & $46 \mathrm{pr}$ & dag & $23 \mathrm{pr}$ & $4+\mathrm{pr}$ \\
\hline \multicolumn{7}{|c|}{$\begin{array}{l}\text { Sylotoy og annot } \\
\text { sott palegg. }\end{array}$} \\
\hline \multicolumn{7}{|c|}{ Brun ost, helfet } \\
\hline \multicolumn{7}{|l|}{$\begin{array}{l}\text { Brun ost, } \\
\text { halvfetimager }\end{array}$} \\
\hline \multicolumn{7}{|l|}{ Hvit ost, helfet } \\
\hline \multicolumn{7}{|l|}{$\begin{array}{l}\text { Huit ost, } \\
\text { halvfet'mager }\end{array}$} \\
\hline $\begin{array}{l}\text { Kottpálegg, } \\
\text { leverpostel }\end{array}$ & & & & & & \\
\hline
\end{tabular}

Videre kommer spørsmål om fiskepålegg.

På hvor mange brodskiver pr. uke har du i

gjennomsnitt siste året spist? (Sett ett kryss pr. linje)

\begin{tabular}{|c|c|c|c|c|c|c|}
\hline & pro uke & pruke & $\begin{array}{l}23 \\
\text { pruke }\end{array}$ & $\begin{array}{l}46 . \\
\text { prove }\end{array}$ & $77^{7}$ & $10+$ \\
\hline $\begin{array}{l}\text { Nakroll i tomat, } \\
\text { rokt malsrell }\end{array}$ & & & & & & \\
\hline Kaviar & & & & & & \\
\hline Annet fiskepalegg & & & & & & \\
\hline
\end{tabular}

Hva slags fett bruker du vanligvis på brodet?

(Sett gjerne flere kryss)

$\begin{array}{ll}\square & \text { bruker ikke fett på brødet } \\ \square \quad & \text { smør } \\ \square & \text { hard margarin (f. eks. Per, Melange) } \\ \square & \text { myk margarin (f. eks. Soft) } \\ \square & \text { smørblandet margarin (f. eks. Bremykt) } \\ \square & \text { Brelett } \\ \square \quad \text { lettmargarin (f. eks. Soft light, Letta) }\end{array}$

Dersom du bruker fett på brødet, hvor tykt lag pleier du smøre på? (En kuvertpakke med margarin veier 12 gram). (Sett ett kryss)

$\square$ skrapet (3 g) $\square$ tynt lag (5 g) $\square$ godt dekket (8 g)

$\square$ tykt lag (12 g)

Hvor ofte spiser du frukt? (Sett ett kryss pr. linje)

\begin{tabular}{|c|c|c|c|c|c|c|c|}
\hline & aldry & mind & 1 pre & 24 pri. & 56 pre & dag & 2+ pr. \\
\hline \multicolumn{8}{|l|}{ Eplerperer } \\
\hline \multicolumn{8}{|l|}{ Appelsiner oll } \\
\hline \multicolumn{8}{|l|}{ Bananer } \\
\hline $\begin{array}{l}\text { Annen trukt } \\
\text { (teks. druer, fersken) }\end{array}$ & & & & & & & \\
\hline
\end{tabular}


Hvor ofte spiser du ulike typer grønnsaker? (Sett ett kryss pr. linje)

\begin{tabular}{|l|c|c|c|c|c|c|c|}
\hline & $\begin{array}{c}\text { aldriv } \\
\text { sjelden }\end{array}$ & $\begin{array}{c}\text { 1-3 pr. } \\
\text { mnd }\end{array}$ & $\begin{array}{c}\text { p pr. } \\
\text { uke }\end{array}$ & $\begin{array}{c}\text { 2 pr. } \\
\text { uke }\end{array}$ & $\begin{array}{c}\text { 3 pr. } \\
\text { uke }\end{array}$ & $\begin{array}{c}\text { 4-5 pr. } \\
\text { uke }\end{array}$ & $\begin{array}{c}\text { 6-7 pr. } \\
\text { uke }\end{array}$ \\
\hline Gulrotter & & & & & & & \\
\hline Kål & & & & & & & \\
\hline Kálrot & & & & & & & \\
\hline Broccoliblomkál & & & & & & & \\
\hline Blandet salat & & & & & & & \\
\hline $\begin{array}{l}\text { Gronnsakblanding } \\
\text { (frossen) }\end{array}$ & & & & & & & \\
\hline Andre grønnsaker & & & & & & & \\
\hline
\end{tabular}

For de gronnsakene du spiser, kryss av for hvor mye du spiser hver gang. (Sett ett kryss for hver sort)

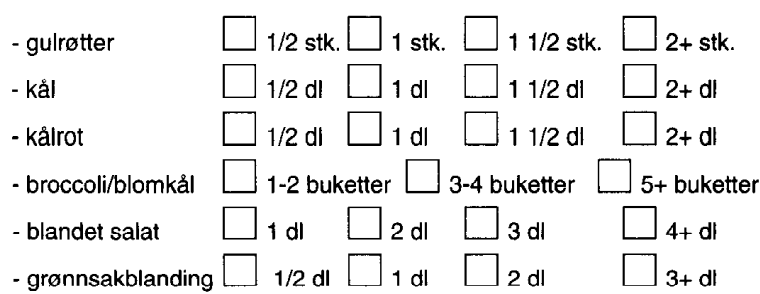

Hvor mange poteter spiser du vanligvis (kokte, stekte, mos)? (Sett ett kryss)

$\square$ spiser ikke/spiser sjelden poteter

$\begin{array}{ll}\square \text { 1-4 pr. uke } & \square \text { 5-6 pr. uke } \\ \square \text { 1 pr. dag } & \square \text { 2 pr. dag } \\ \square \text { 3 pr. dag } & \square \text { 4+ prdag }\end{array}$

Hvor ofte bruker du ris og spaghetti/makaroni ? (Sett ett kryss pr. linje)

\begin{tabular}{|l|c|c|c|c|c|}
\hline & $\begin{array}{c}\text { aldry } \\
\text { sjelden }\end{array}$ & $\begin{array}{c}1-3 \text { pr. } \\
\text { mnd }\end{array}$ & $\begin{array}{c}\text { 1 pr. } \\
\text { uke }\end{array}$ & $\begin{array}{c}\text { 2 pr. } \\
\text { uke }\end{array}$ & $\begin{array}{c}3+\text { pr. } \\
\text { uke }\end{array}$ \\
\hline Ris & & & & & \\
\hline $\begin{array}{l}\text { Spaghettl, } \\
\text { makaronl }\end{array}$ & & & & & \\
\hline
\end{tabular}

Hvor ofte spiser du risengrynsgrot? (Sett ett kryss)

$\square$ aldri/sjelden $\square_{1 \text { pr. mnd }} \square$ 2-3 pr. mnd $\square_{1+\text { pr. uke }}$

Hva slags fett blir vanligvis brukt til matlaging i din husholdning? (Sett gierne flere kryss)

$\square$ smør

$\square$ hard margarin (f. eks. Per, Melange)

$\square$ myk margarin (f. eks. Soft)

$\square$ smørblandet margarin (f. eks. Bremykt)

$\square$ soyaolje $\quad \square$ olivenolje $\quad \square$ maisolje

\section{Fisk}

Vi vil gjerne vite hvor ofte du pleier å spise fisk, og ber deg fylle ut spørsmålene om fiskeforbruk så godt du kan. Tilgangen på fisk kan variere gjennom året. Vær vennlig å markere i hvilke ârstider du spiser de ulike fiskeslagene.

\begin{tabular}{|c|c|c|c|c|c|c|}
\hline & $\begin{array}{l}\text { aldriy } \\
\text { sjelden }\end{array}$ & \begin{tabular}{|l} 
like mye \\
hele áret
\end{tabular} & vinter & văr & sommer & host \\
\hline \multicolumn{7}{|c|}{ Torsk, sel, hyse, lyr } \\
\hline \multicolumn{7}{|c|}{ Steinblt, flyndre, uer } \\
\hline \multicolumn{7}{|c|}{ Laks, ørret } \\
\hline \multicolumn{7}{|c|}{ Makrell } \\
\hline SIld & & & & & & \\
\hline
\end{tabular}

Med tanke på de periodene av året der du spiser fisk, hvor ofte pleier du å spise følgende? (Sett ett kryss pr. linje)

\begin{tabular}{|l|l|l|l|l|l|l|}
\hline & $\begin{array}{c}\text { aldril } \\
\text { sjelden }\end{array}$ & $\begin{array}{c}1 \text { pr. } \\
\text { mnd }\end{array}$ & $\begin{array}{c}2-3 \text { pr. } \\
\text { mnd }\end{array}$ & $\begin{array}{c}\text { 1 pr. } \\
\text { uke }\end{array}$ & $\begin{array}{c}\text { 2 pr. } \\
\text { uke }\end{array}$ & $\begin{array}{c}\text { 3+pr. } \\
\text { uke }\end{array}$ \\
\hline $\begin{array}{l}\text { Kold torsk, } \\
\text { sei, hrse. lyr }\end{array}$ & & & & & & \\
\hline $\begin{array}{l}\text { Stekt torsk, } \\
\text { sel, hyse. Iyr }\end{array}$ & & & & & & \\
\hline $\begin{array}{l}\text { Steinbit, } \\
\text { flyndre, uer }\end{array}$ & & & & & & \\
\hline Laks, orret & & & & & & \\
\hline Makrell & & & & & & \\
\hline Sild & & & & & & \\
\hline
\end{tabular}

Dersom du spiser fisk, hvor mye spiser du vanligvis pr. gang? $(1$ skive/stykke = 150 gram $)$ (Sett ett kryss for hver linje)

- kokt fisk (skive) $\quad \square_{1} \quad \square_{1,5} \square_{2} \quad \square$ 3+ - stekt fisk (stykke) $\quad \square_{1} \quad \square_{1,5} \square_{2} \quad \square$ 3+

Hvor mange ganger pr. år spiser du fiskeinnmat? (Sett ett kryss pr. linje)

Rogn

Fiskelever

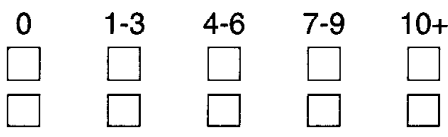

Dersom du spiser fiskelever, hvor mange spiseskjeer pleier du å spise hver gang? (Sett ett kryss)

$\square_{1} \quad \square_{2} \quad \square_{3-4} \quad \square_{5-6} \quad \square_{7+}$

Hvor ofte bruker du følgende typer fiskemat?

(Sett ett kryss pr. linje)

\begin{tabular}{|l|l|l|l|l|l|}
\hline & $\begin{array}{c}\text { aldryl } \\
\text { sjelden }\end{array}$ & $\begin{array}{c}1 \text { pr. } \\
\text { mnd }\end{array}$ & $\begin{array}{c}2-3 \text { pr. } \\
\text { mnd }\end{array}$ & $\begin{array}{c}\text { 1 pr. } \\
\text { uke }\end{array}$ & $\begin{array}{c}\text { 2+ pr. } \\
\text { uke }\end{array}$ \\
\hline $\begin{array}{l}\text { Fiskekaker/pudding/ } \\
\text { boller }\end{array}$ & & & & & \\
\hline $\begin{array}{l}\text { Plukkfisk, } \\
\text { flskegratene }\end{array}$ & & & & & \\
\hline $\begin{array}{l}\text { Frityrfisk, } \\
\text { fiskepinner }\end{array}$ & & & & & \\
\hline Andre fiskeretter & & & & & \\
\hline
\end{tabular}


Hvor stor mengde pleier du vanligvis å spise av de ulike rettene? (Sett ett kryss for hver linje)

- fiskekaker/pudding/boller (stk.) $\square_{1} \quad \square_{2} \quad \square_{3} \quad \square_{4+}$ (2 fiskeboller=1 fiskekake)

- plukkfisk, fiskegrateng (dl)

$\square_{1-2} \square_{3-4} \square 5+$

- frityrfisk, fiskepinner (stk.)

$\square_{1-2} \square_{3-4} \square_{5-6} \square_{7+}$

Hvor ofte spiser du skalldyr (f. eks. reker, krabbe)? (Sett ett kryss)

$\begin{array}{llll}\begin{array}{c}\text { aldril } \\ \text { sjelden }\end{array} & 1 \mathrm{pr} . & 2-3 \mathrm{pr} & 1+\mathrm{pr} . \\ \text { mnd } & \text { mnd }\end{array}$

I tillegg til informasjon om fiskeforbruk er det viktig å fá kartlagt hvilket tilbehør som blir servert til fisk.

Hvor ofte bruker du følgende till fisk? (Sett ett kryss pr. linje)

\begin{tabular}{|c|c|c|c|c|c|}
\hline & $\begin{array}{l}\text { aldrin } \\
\text { sjelden }\end{array}$ & mind & $\begin{array}{l}23 \mathrm{pp} \\
\text { mind }\end{array}$ & Tore & 2+ pike \\
\hline $\begin{array}{l}\text { Smeitet eller fast } \\
\text { margarintet }\end{array}$ & & & & & \\
\hline Seterromme (35\%) & & & & & \\
\hline Lettromme $(20 \%)$ & & & & & \\
\hline Saus med tott (hvithrun) & & & & & \\
\hline Saus uten tet (huilbrun) & & & & & \\
\hline
\end{tabular}

For de ulike typene tilbehør du bruker til fisk, vær vennlig å kryss av for hvor mye du vanligvis pleier spise.

- smeltet/fast fett (ss) $\quad \square_{1 / 2} \quad \square_{1} \quad \square_{2} \quad \square_{3} \quad \square_{4+}$

- seterramme (ss) $\square_{1 / 2} \square_{1} \quad \Pi_{2} \quad \Pi_{3} \quad \Pi_{4+}$

- letrømme (ss) $\quad \square_{1 / 2} \quad \square_{1} \quad \square_{2} \quad \square_{3} \quad \square_{4+}$

saus med fett (dl) $\quad \square_{1 / 4} \square_{1 / 2} \square_{3 / 4} \square_{1} \square_{2+}$

saus uten fett (dl) $\quad \square_{1 / 4} \quad \square_{1 / 2} \quad \square_{3 / 4} \square_{1} \quad \square_{2+}$

\section{Andre matvarer}

Hvor ofte spiser du følgende kjøtt- og fjærkreretter? (Sett ett kryss for hver rett)

\begin{tabular}{|c|c|c|c|c|c|}
\hline & slary & $\begin{array}{l}1 \mathrm{pr} \\
\mathrm{mnd}\end{array}$ & $\begin{array}{c}2-3 \mathrm{pp} \\
\mathrm{mnd}\end{array}$ & T pro & $2+\mathrm{pr}$ \\
\hline \multicolumn{6}{|c|}{ Steik (okse, svin, far) } \\
\hline \multicolumn{6}{|l|}{ Kateletter } \\
\hline \multicolumn{6}{|l|}{ Biff } \\
\hline \multicolumn{6}{|c|}{ Kjotkaker, karbonader } \\
\hline \multicolumn{6}{|l|}{ Polser } \\
\hline \multicolumn{6}{|c|}{ Gryterett, lapskaus } \\
\hline \multicolumn{6}{|l|}{ Pizza m/kjett } \\
\hline \multicolumn{6}{|l|}{ Kylling } \\
\hline Andre kjottretter & & & & & \\
\hline
\end{tabular}

Dersom du spiser følgende retter, oppgi mengden du vanligvis spiser: (Sett ett kryss for hver linje)

- steik (skiver)

- koteletter(stk.)

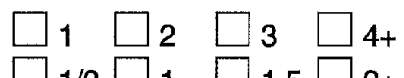

- kjøttkaker,

karbonader (stk.)

- pølser (stk. à 150g)

- gryterett, lapskaus (dl)

$\square_{1 / 2} \square_{1} \square 1,5 \square 2+$ - pizza m/kjøtt (stykke à 100 g) $\square_{1} \quad \square_{2} \quad \square_{3} \quad \square_{4+}$

Hvor mange egg spiser du vanligvis i løpet av en uke (stekte, kokte, eggerøre, omelett)? (Sett ett kryss)

$\square_{0} \quad \square_{1} \quad \square_{2} \quad \square_{3-4} \quad \square_{5-6} \quad \square_{7+}$

Vi ber deg fylle ut hovedrettene til middag en gang til som en oppsummering. Kryss av $i$ den ruten som passer hvor ofte du i gjennomsnitt $\mathrm{i}$ løpet av siste ăr har spist slik mat til middag

Rent kjøtt $\begin{array}{cccccccc}5+ & 4 & 3 & 2 & 1 & 2-3 & 1 & \text { nesten } \\ \text { pr. } & \text { pr. } & \text { pr. } & \text { pr. } & \text { pr. } & \text { pr. } & \text { pr. } & \text { aldri } \\ \text { uke } & \text { uke } & \text { uke } & \text { uke } & \text { uke } & \text { mnd } & \text { mnd }\end{array}$

Oppmalt kjøtt

Fet fisk (makrell, laks o.l.)

Mager fisk

(torsk o.I.)

$\square_{1} \square_{2} \square_{3} \square_{4+}$ $\square_{1 / 2} \square_{1} \quad \square_{1,5} \square_{2+}$

Fiskemat

Hvor ofte spiser du iskrem (til dessert, krone-is osv.)?

(Sett ett kryss for hvor ofte du spiser iskrem om sommeren, og ett kryss for resten av äret)

- om sommeren

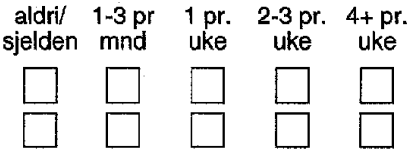

- resten av året

Hvor mye is spiser du vanligvis pr. gang? (Sett ett kryss)

$\square$ 1 dl $\square 2$ dl $\square 3$ dl $\square$ 4+dl

Hvor ofte spiser du bakervarer som boller, kaker, wienerbrød, vafler, småkaker? (Sett ett kryss)

\begin{tabular}{|c|c|c|c|c|c|c|}
\hline & $\begin{array}{l}\text { aldity } \\
\text { sielden }\end{array}$ & $t_{\mathrm{mid}}^{3} \mathrm{p}$ & $\begin{array}{l}1 \text { pr } \\
\text { uke }\end{array}$ & $28 \mathrm{pr}$ & $\begin{array}{r}46 \mathrm{pl} \\
\mathrm{ukg}\end{array}$ & $\begin{array}{c}7+p_{1} \\
\text { uke }\end{array}$ \\
\hline \multicolumn{7}{|c|}{ Gjeerbakst(boller) } \\
\hline \multicolumn{7}{|l|}{ Kaker } \\
\hline \multicolumn{7}{|c|}{ Pannekaker } \\
\hline \multicolumn{7}{|l|}{ Vafler } \\
\hline Smàkaker & & & & & & \\
\hline
\end{tabular}

Hvor ofte spiser du dessert? (Sett ett kryss)

\begin{tabular}{|c|c|c|c|c|c|c|}
\hline Wr) & $\begin{array}{l}\text { aldit } \\
\text { sjelden }\end{array}$ & $\begin{array}{l}13 \text { pri } \\
\text { nnd }\end{array}$ & $\begin{array}{l}1 \text { pr. } \\
\text { oke }\end{array}$ & $\begin{array}{r}23 p r \\
\text { une }\end{array}$ & $\begin{array}{r}46 \mathrm{pr} \\
\text { uke }\end{array}$ & $\begin{array}{c}7+\mathrm{pr} \\
\text { uke }\end{array}$ \\
\hline $\begin{array}{l}\text { Pudoding } \\
\text { sjokolader taramell }\end{array}$ & & & & & & \\
\hline $\begin{array}{l}\text { Rlstrem, } \\
\text { tromasi }\end{array}$ & & & & & & \\
\hline $\begin{array}{l}\text { kompott fruktgrot } \\
\text { hermetist trukt }\end{array}$ & & & & & & \\
\hline
\end{tabular}


Hvor ofte spiser du sjokolade? (Sett ett kryss)

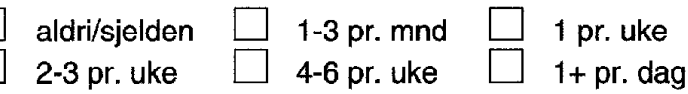

Dersom du spiser sjokolade, hvor mye pleier du vanligvis å spise hver gang? Tenk deg størrelsen på en Kvikk-Lunsj sjokolade, og oppgi hvor mye du spiser i forhold til den.

\section{$\square_{1 / 4} \square_{1 / 2} \quad \square_{3 / 4} \square_{1} \square_{1,5} \square_{2+}$}

Hvor ofte spiser du salt snacks? (Sett ett kryss)

\begin{tabular}{|c|c|c|c|c|c|c|}
\hline & $\begin{array}{l}\text { aldirl } \\
\text { sielden }\end{array}$ & $\begin{array}{l}1-3 \mathrm{pg} \\
\mathrm{mnd}\end{array}$ & $1 \mathrm{pre}$ & 2-3p & $\begin{array}{l}46 \mathrm{pr} \\
\mathrm{kke}\end{array}$ & $\begin{array}{r}7+p r \\
\text { ule }\end{array}$ \\
\hline Potetchips & & & & & & \\
\hline Peanolter & & & & & & \\
\hline
\end{tabular}

\section{Tilberedningsmåte}

Har du mikrobelgeovn?

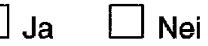

Hvis Ja; hvor mange ganger pr. uke bruker du mikrobølgeovnen til middagslaging? annet?

ganger pr. uke

............

\section{...................}

Hvilken farve foretrekker du pá stekeskorpen?
$\square$ Lys brun
$\square$ Middels
$\square$ Mørk brun

Hvor ofte spiser du stekt eller grillet mat?

\begin{tabular}{|c|c|c|c|c|c|c|}
\hline Ple & $\begin{array}{l}\text { aldir } \\
\text { sielosen }\end{array}$ & mis & ule & 23pre & 4.6p & $\begin{array}{c}7+p: \\
\text { wee }\end{array}$ \\
\hline \multicolumn{7}{|c|}{$\begin{array}{l}\text { Morkt kioti } \\
\text { (bif ol }\end{array}$} \\
\hline \multicolumn{7}{|c|}{$\begin{array}{l}\text { Gri kiett } \\
\text { (ky ing of }\end{array}$} \\
\hline \multicolumn{7}{|c|}{ 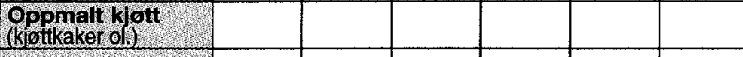 } \\
\hline \multicolumn{7}{|l|}{ Bacon } \\
\hline Fisk & & & & & & \\
\hline
\end{tabular}

Bruker du stekefettet eller sjyen etter steking?
$\square$ nei, aldri
$\square$ som oftest
$\square$ av og til
$\square$ ja, alltid

\section{Tran og fiskeoljekapsler}

Bruker du tran (flytende)? $\square$ Ja $\square$ Nei

Hvis ja; hvor ofte tar du tran?

Sett ett kryss for hver linje.

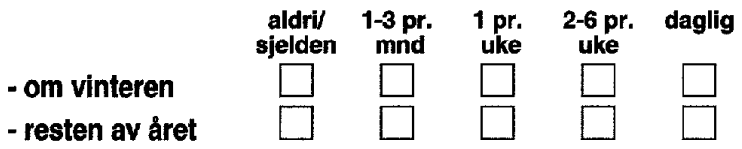

Hvor mye tran pleier du å ta hver gang?

$$
1 \text { ts } \square 1 / 2 s s \quad \square 1+s s
$$

Bruker du tranpiller/kapsler? $\square$ Ja $\square$ Nei

Hvis ja; hvor ofte tar du tranpiller/kapsler?

Sett ett kryss for hver linje.

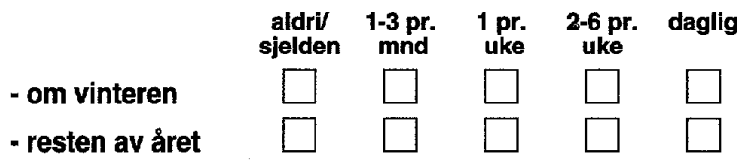

Hvilken type tranpiller/kapsler bruker du vanligvis, og hvor mange pleier du å ta hver gang?

$$
\text { ja antall pr. gang }
$$

Møllers trankapsler

Møllers omega-3 kapsler

Møllers dobbel

annet, navn

Bruker du fiskeoljekapsier? $\square$ Ja $\quad \square$ Nei Hvis ja; hvor ofte tar du fiskeoljekapsler?

$\begin{array}{ccccc}\begin{array}{c}\text { aldril } \\ \text { sjelden }\end{array} & \begin{array}{c}1-3 \text { pr. } \\ \text { mnd }\end{array} & \begin{array}{c}1 \text { pr. } \\ \text { uke }\end{array} & \begin{array}{c}\text { 2-6 pr. } \\ \text { uke }\end{array} & \text { daglig } \\ \square & \prod & \square & \square & \square\end{array}$

Hvilken type fiskeoljekapsler bruker du vanligvis, og hvor mange pleier du å ta hver gang?

$$
\text { ja antall pr. gang }
$$

Triomar

Almarin

Nycomed Omega-3

annet, navn

\section{Kostiliskudd}

Bruker du annet kosttilskudd (eks. vitaminer, mineraler)?

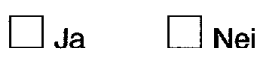

Hvis ja; hvor ofte tar du slike kosttilskudd?

$\begin{array}{cccc}\begin{array}{c}\text { aldrif } \\ \text { sjelden }\end{array} & \begin{array}{c}1-3 \text { pr. } \\ \text { mnd }\end{array} & \begin{array}{c}\text { 1 pr. } \\ \text { uke }\end{array} & \begin{array}{c}2-6 \text { pr. } \\ \text { uke }\end{array} \\ \square & \square & \text { daglig }\end{array}$

Navn

\section{Alkohol}

Er du total avholdskvinne? $\quad \square$ Ja $\quad \square$ Nei Hvis Nei, hvor ofte og hvor mye drakk du I gjennomsnitt siste året? (Sett ett kryss for hver linje) aldri
sjelden
mnd

$\varnothing 1(1 / 2 L)$

Vin (glass)

Brennevin
(drinker) 